\title{
Relationship of Family Income and Family Support with Maternal Reference in Pregnant Women in Pantai Cermin BEmONC, Langkat District, 2019
}

\author{
Siti Maryam Hsb ${ }^{1}$, Heru Santosa ${ }^{1}$, Asfriyati ${ }^{1}$ \\ ${ }^{1}$ Masters Program in Public Health, Universitas Sumatera Utara, Indonesia \\ maryamhasibuan08@gmail.com
}

\begin{abstract}
Basic emergency obstetric and newborn care (BEmONC) is an inpatient Publlich Health Center that is able to provide obstetric and neonatal emergency/ basic complications services 24 hours a day and 7 days a week. In Public Health Center the referral service ideally is no more than $15 \%$, the high number of maternal referrals in BEMONC Pantai Cermin Langkat District exceeds the Standard (> 15\%). The number of maternal referrals in pregnant women starting from 1 May 2018 to 31 October 2018 was 104 people. Factors related to maternal referral to pregnant women in Pantai Cermin BEmONC, Langkat district are maternal knowledge, and support of health workers. The purpose of this study was to determine the relationship of maternal knowledge, and support of he alth workers with the maternal referral process in pregnant women. This study used a cross sectional design, with 104 pregnant women being referred at Pantai Cermin BEmONC, Langkat district by method of total sampling. Data collection methods consist of primary data and secondary data. Based on the results of the study note that out of 104 respondents there were 54 (51.9\%) maternal referral processes in incompatible pregnant women and 50 (48.1\%) maternal referral processes in pregnant women in accordance with the reference standard. Variables related to the maternal referral process in pregnant women were family income $(p=0.049)$, and family support $(p=0.028)$.There is a relationship between family income and family support with the maternal referral process for pregnant women at the BEMONC Public Health Center Pantai Cermin Langkat Regency.
\end{abstract}

Keywords

maternal referral; family

income; family support

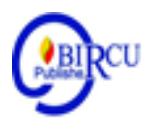

\section{Introduction}

Health is a very important element of the quality of life in national development. The national health system has established that the goal of health development is to increase awareness, willingness, and ability to live healthy for everyone so that a high degree of public health can be realized - high human resources, as an investment for socially and economically productive development (Health Law No. 36 of 2009).

In realizing the optimal health degree, the role of prime health service is needed. Health care is one of the determinants of the degree of public health. One of the targets is the Public Health Center. It is a functional unit which is a center of community health development that also fosters community participation and provides comprehensive and integrated services to the community in its working area in the form of main activities. Public Health Center have the authority and responsibility for maintaining public health in their working area $(\mathrm{MOH}$, 2009). 
The existence of Public Health Center in the community is very important because the Public Health Center are the spearhead of health services provided by local governments. Individual health efforts at Public Health Center are related to sick behavior and treatment seeking behavior in sick people. Health services implemented by health centers must be able to satisfy the community as service users (Ahmadi, 2008).

Based on the level of utilization (utility) of the community, especially the urban middle class and above, health services such as health centers as a place for treatment and health checks tend to be low. They prefer medical clinic services, specialist medical practices, and private hospitals to Public Health Center. This condition reinforces the stereotype of many circles that Public Health Center are still considered second-class health services. As the disease continues to threaten the community, the government must reorganize the role and function of the Public Health Center as a public health institution engaged in development, therefore revitalization of the Public Health Center is needed (Mubarak, 2007). One of the goals of the Sustainable Development Goals (SDGs) is to achieve the target of reducing maternal mortality to below 70 per 100,000 live births by 2030 . To achieve this goal the government pursues strategies and efforts, one of which is through the $\mathrm{MCH}$ program.

The results of the Indonesian Demographic Health Survey (SDKI) in 2012, said the maternal mortality rate jumped dramatically to 359 / 100,000 live births in 2012. Whereas previously the maternal mortality rate could be from 390 / 100,000 live births (1991), to 228 / 100,000 live births (2007) (Indonesia Health Profile, 2014). Seeing the problems that occur in an effort to reduce MMR, it requires more conducive efforts and commitment support from all central and regional stakeholders. One of the efforts that have been carried out to accelerate the reduction of MMR is through obstetric and neonatal emergency / complication handling at the basic service level, namely through efforts to implement Public Health Center Capable of Basic Emergency Neonatal Obstetric Services (BEmONC).

Providing health facilities with Basic Emergency Neonatal Obstetric Services (BEmONC) at the Public Health Center is expected to reduce the degree of morbidity and minimize the number of deaths of mothers and babies in Indonesia. Realization from the government at the level of health centers that have general practitioners and midwives, especially Public Health Center with inpatients developed into a health center that provides Basic Emergency Obstetric and Neonatal Services (BEmONC). The BEmONC of Public Health Center is the closest referral place from the village as a midwife coach and brings emergency access services to pregnant and childbirth women because complications in pregnancy and childbirth cannot be predicted or predicted beforehand.

Pantai Cermin Public Health Center is a health center located in Langkat Regency and is a BEmONC of health center. The results of a preliminary survey conducted showed that maternal services at the BEmONC of health center were still low. This indicates that the $\mathrm{BEmONC}$ of health center has not been fully utilized by the community. There are still many people who do maternal referral at the Public Health Center.

Based on Permenkes No. 001 of 2012 concerning the individual health service referral system states that health services are carried out in stages so that the referral system is an obligation that must be carried out by the first level of health service center (Kemenkes, 2012). This referral is given to BPJS patients if the BEmONC cannot provide health services according to the patient's needs due to limited facilities, services and staffing, as well as a diagnosis of patients beyond 155 diagnoses that must be served at the BEmONC (BPJS Health, 2014). In BEmONC the referral service coverage ideally is not more than 15 percent, based on Yuniar Simanjuntak research (2017) in Medan Johor BEmONC is BPJS patient 
referral service achievement is still said to be high from 2014 to 2016 which is still above 15 percent.

The high number of maternal referral cases in Pantai Cermin Public Health Center that exceeds the standard (>15\%) indicates that there is an inappropriate referral system. There are several factors that cause the high maternal referral in Pantai Cermin Public Health Center.

Based on the results of interviews it is known that the level of community income is still low because the income is still below the stipulated minimum wage $(<R$. 2,500,000). They generally work as farmers, cracker sellers, pedicabs' drivers, and fishermen. Income obtained is only able to cover basic needs such as food and school for a month. This is the reason they asked to be referred because with the help of BPJS Health, the cost of treatment at the hospital becomes free.

\section{Review of Literature}

Family support according to Friedman (2010) is an attitude, the act of family acceptance of family members, in the form of informational support, assessment support, instrumental support and emotional support. So family support is a form of interpersonal relationships that include attitudes, actions and acceptance of family members, so that family members feel someone is paying attention. So family social support refers to social supports that are seen by family members as something that can be accessed or held for families who are always ready to provide help and assistance if needed (Erdiana, 2015). According to Murdock in Lestari (2012) outlines that the family is a social group that has the characteristics of living together, there is economic cooperation, and the reproductive process occurs. Form of family support. There are some that fall into the form of family support:

\section{Informational Support}

This type of support includes communication networks and the responsibility of providing advice, direction, advice, or feedback about what a family member does can provide information by suggesting about doctors, but which is good for him, and specific actions for individuals to fight stressors. Individuals who are depressed can get out of their problems and solve their problems with the support of the family by providing feedback, in this information support the family as a collector of information and information givers.

2. Assessment Support

This support includes help for individuals to understand the incidence of depression well as well as sources of depression and coping strategies that can be used in dealing with stressors. This support is also the support that occurs when there are expressions of positive judgment on individuals. Individuals have someone who can talk about their problems, occurring through the expression of positive expectations of individuals to other individuals, encouragement, approval of one's ideas or feelings and positive comparison of someone with others, for example people who are less able. Family support can help improve individual coping strategies with alternative strategies based on experience that focuses on positive aspects.

3. Instrumental Support

This support includes the provision of physical support such as services, financial and material assistance in the form of tangible assistance (instrumental support material support). A condition where objects or services will help solve practical problems, including direct assistance, such as when someone gives or lends money, helps with daily work, delivers messages, provides transportation, maintains and cares for illness or 
depression that can help solve problem. Real support is most effective when valued by individuals and reduces individual depression. On real family support as a source for achieving practical goals and tangible goals.

4. Emotional Support

During depression, individuals often suffer emotionally, sadly, anxiously, and lose selfesteem. If depression reduces one's feelings of belonging and being loved. Emotional support gives individuals a feeling of comfort, feeling loved when experiencing depression, assistance in the form of enthusiasm, empathy, trust, attention so that the individual who receives it feels valued. In this emotional support the family provides a place of rest and encourages.

Family support according to Friedman (2010) is an attitude, the act of family acceptance of family members, in the form of informational support, assessment support, instrumental support and emotional support. So family support is a form of interpersonal relationships that include attitudes, actions and acceptance of family members, so that family members feel someone is paying attention. So family social support refers to social supports that are seen by family members as something that can be accessed or held for families who are always ready to provide help and assistance if needed (Erdiana, 2015).

Lack of family support will affect the motivation or desire of family members to check their health. Social support can be in the form of providing information, behavioral assistance, or material obtained from intimate social relationships that can make individuals feel cared for, valued and loved. Based on the research results Nurlinta et al. (2014), family support influences decisions in choosing a place of delivery. Indira (2014) in BEmONC Deli Serdang District stated that BEmONC supporting facilities and infrastructure were still inadequate, BEmONC training was still lacking, patient referral procedures for emergency mothers had not been carried out properly, so the referral process at the Deli Serdang BEmONC was not as expected. Juliwanto (2015) shows that there is a significant relationship between family support for the decision to choose birth attendants for pregnant women. The results of the Prime Research (2015) also showed that the search for health services for pregnant women based on social community in the Coastal Region of Lasolo District, North Konawe Regency in 2015.

Family support also influences mothers in making maternal referrals. The family is more motivated to give birth in the hospital so they prefer to be referred. Their family said that the facilities in the hospital were more complete so that if complications occur they could be dealt with immediately. The existence of family support, both biological mothers, motherin-law and other nuclear families have a significant share of the maternal referral process in pregnant.

\section{Research Method}

This research is an observational analytic study using a cross sectional study design. The population in this study were all pregnant women who were referred from May 12018 31 October 2018, who were registered at the Pantai Cermin Health Center in Langkat Regency as many as 104 people. While the sample in this study is total sampling in which the entire population is used as a research sample of 104 pregnant women.

Data collection method is Primary Data is Data obtained from direct observation to the field through interviews and observations based on a questionnaire that has been prepared by researchers.Secondary Data is Data obtained from the profiles of the Langkat District Health 
Office and Pantai Cermin BEmONC. Retrieval of research data was carried out after obtaining permission from Pantai Cermin BEmONC Langkat District, then providing an explanation to the respondent, requesting the respondent's willingness and filling out informed consent, giving a questionnaire. The data obtained were then processed using a computer program that is SPSS using univariate, bivariate analysis.

\section{Results}

This study the majority of low family income is $53(51.0 \%)$. In the distribution of frequency of respondents based on family support the majority did not support that is 62 (59.6\%). While the frequency distribution of respondents based on the maternal referral process in the majority of pregnant women is not appropriate, namely $54(51.9 \%)$. Characteristics of respondents can be seen in Table 1. The relationship of family income with the maternal referral process in pregnant women can be seen in Table 2. The relationship of family support with the maternal referral process can be seen in Table 3.

Table 1. Characteristics of Respondents by Family Income, Family Support, and the Maternal Referral Process for Pregnant Women.

\begin{tabular}{llcc}
\hline No & \multicolumn{1}{c}{ Characteristic } & N & $\begin{array}{c}\text { Percentag } \\
\text { e (\%) }\end{array}$ \\
\hline $\mathbf{1}$ & Family Income & & \\
& Low & 53 & 51,0 \\
& High & 51 & 49,0 \\
\hline & Jumlah & $\mathbf{1 0 4}$ & $\mathbf{1 0 0}$ \\
\hline $\mathbf{2}$ & Family Support & & \\
& No support & 62 & 59,6 \\
& Support & 42 & 40,4 \\
\hline & Total & $\mathbf{1 0 4}$ & $\mathbf{1 0 0}$ \\
\hline $\mathbf{3}$ & Process & & \\
& Maternal Reference to & & \\
& Pregnant Women & & \\
& Not appropriate & $\mathbf{5 4}$ & $\mathbf{5 1 , 9}$ \\
& appropriate & $\mathbf{5 0}$ & $\mathbf{4 8 , 1}$ \\
\hline & Total & $\mathbf{1 0 4}$ & $\mathbf{1 0 0}$ \\
\hline
\end{tabular}

Table 2. Relationship of family income with maternal referral process for pregnant women

\begin{tabular}{lccc}
\hline & \multicolumn{2}{c}{$\begin{array}{c}\text { Maternal Referral Process } \\
\text { in Pregnant Women }\end{array}$} & $\boldsymbol{\rho}$ \\
\cline { 2 - 3 } & $\begin{array}{c}\text { Not } \\
\text { Appropriate }\end{array}$ & Appropriate & \\
\hline & & & \\
\hline Famaly's & & & \\
Income & 33 & 20 & 0,049 \\
Low & 21 & 30 & \\
High & & & \\
\hline
\end{tabular}

The results of the analysis using Che-Square test revealed that there was a relationship between family income and the maternal referral process for pregnant women at Pantai Cermin BEmONC, Langkat Regency because the value of $\mathrm{p}=0.049(\mathrm{p}<0.05)$. 
Table 3. Relationship of family support with the Maternal Referral Process in Pregnant Women

\begin{tabular}{lccc}
\hline & \multicolumn{2}{c}{$\begin{array}{c}\text { Maternal Referral Process in } \\
\text { Pregnant Women }\end{array}$} & $\rho$ \\
\cline { 2 - 3 } & $\begin{array}{c}\text { Not } \\
\text { Appropriate }\end{array}$ & Appropriate & \\
\hline Family & & & \\
Support & & 24 & \\
Not support & 38 & 26 & 0,02 \\
support & 16 & & 8 \\
& & & \\
& & &
\end{tabular}

The results of the analysis using the Che-Square test revealed that there was a relationship of family support to the maternal referral process for pregnant women at Pantai Cermin BEmONC, Langkat Regency because the value of $p=0.028(p<0.05)$.

The relationship of maternal income to the maternal referral process in pregnant women. The results of the study mostly have a low income as many as 53 people $(51.0 \%)$ and a small part have a high income that is as much as $51(49.0 \%)$ The results of hypothesis testing using chi square obtained a $\mathrm{p}$ value of 0.049 which means there is a relationship between income families with a maternal referral process for pregnant women at Pantai Cermin BEmONC of Langkat district. Family income is important in meeting basic needs (primary) and secondary needs, families with good economic status will be more easily met their needs compared to families with low economic status. Financial preparation is very necessary in preparation for the process of pregnancy, childbirth and the puerperium and complications that may occur. Family income also influences the decision making of maternal referral, in this case the choice of place of delivery. The results of this study are in line with Juliwanto's research (2015) which shows that there is a significant relationship between family income and work towards maternal referral in pregnant women. Sibua (2015) also states that there is a significant relationship between income and referral services with a $\mathrm{p}$ value of 0.005.Napirah et al (2016) also states that income has a relationship with decision making in health services in the Tambarana Healt Center. There are still many people in the working area of Tambarana Health Center who have incomes below the regional minimum wage. This study is in line with the research of Syam et al (2015) that there is a relationship between knowledge, health facilities, personal autonomy, support of health workers, and access to information with decision making by pregnant women in the search for health services. The results of Juliwanto's research (2012) show that there is a significant relationship between family income and work regarding the decision to choose birth attendants for pregnant women.

\section{Conclusion}

The relationship of family support to the maternal referral process in pregnant women. The results of the study that the majority of family support variables do not support as many as 62 people $(59.6 \%)$ and a small portion of support that is as much as $42(40.4 \%)$. The results of hypothesis testing using chi square obtained a $\mathrm{p}$ value of 0.028 which means that there is a relationship between family support for the maternal referral process for pregnant women at the Pantai Cermin BEmONC of Langkat Regency. 
Notoatmodjo (2003) states that the component that allows behavior to occur is the presence of family support such as facilities in the family. Forms of family support in the form of emotional support, instrumental support, assessment support and information support. Emotional social support includes caring, empathy, love, attention and trust. Instrumental support, namely support that is tangible or in the form of material that aims to ease the burden on individuals who need it. Information support is support carried out by providing information, advice and instructions on how to solve problems. Appraisal support, namely communication about information relevant to self-evaluation, can take the form of guidance and assistance to solve the problem at hand.

Indira (2014) in BEmONC of Deli Serdang District stated that BEmONC supporting facilities and infrastructure were still inadequate, BEmONC training was still lacking, patient referral procedures for emergency mothers had not been carried out properly, so the referral process at Deli Serdang BEnONC was not as expected. Juliwanto (2015) shows that there is a significant relationship between family support for the decision to choose birth attendants for pregnant women. The results of the Prime Research (2015) also showed that the search for health services for pregnant women based on social community in the Coastal Region of Lasolo District, North Konawe Regency in 2015, showed that family support and knowledge of mothers had a relationship to the search for health services of pregnant women based on social community. The results of this study are in line with the results of research Nurlinta et al (2014) found that family support influences decisions in choosing a place of delivery.

There is a relationship between family income and family support with the maternal referral process for pregnant women at Pantai Cermin BEMONC of Langkat Regency.

\section{References}

Indira, A. (2014). Analisis Pelayanan Ibu Bersalin di Puskesmas PONED Kabupaten Deli Serdang (Studi Kasus di Puskesmas Talun Kenas dan Puskesmas Hamparan Perak). Thesis: Unuversitas Sumatera Utara.

Juliwanto. (2012). Faktor-faktor yang mempengaruhi keputusan memilih penolong persalinan pada ibu hamil Kecamatan Babul Rahmah Kabupaten Aceh Tenggara.

Kesehatan Indonesia Tahun 2014. Profil Kementerian Kesehatan Republik Indonesia 2014

Notoatmodjo, S. (2010). Pendidikan dan Perilaku Kesehatan. Jakarta: PT Rineka Cipta.

Notoatmodjo, S. (2003). Pendidikan dan Perilaku Kesehatan. Jakarta: PT Rineka Cipta.

Notoadmodjo. S. (2005). Promosi Kesehatan dan Teori Aplikasi. Jakarta: PT Rineka Cipta.

Profil Kesehatan Indonesia Tahun 2014. Jakarta: Kementerian Kesehatan Republik Indonesia.

Puspitasari, Noviana, Christina Pernatun Kismoyo, Ida Rumawat Astuti. (2014). Pengetahuan dengan Sikap Ibu Hamil tentang Pelayanan Obstetri Neonatal Emergency Dasar (PONED). Journal of Ilmu Kebidanan, Vol. 2, No. 1

Putri, Aira, Restuning Widiasih, Mira Trisyani. (2012). Rencana Pemilihan Penolong dan Tempat Persalinan Ibu Hamil Setelah Diberikan Pendidikan Kesehatan tentang Persiapan Persalinan Aman. Fakultas Ilmu Keperawatan Universitas Padjajaran. Jawa Barat.

Perdana (2015). Pola Pencarian pelayanan kesehatan ibu hamil berdasarkan sosial dan budaya di wilayah Pesisir Kecamatan Lasolo Kabupaten Konawe Utara. Thesis: Universitas Hasanuddin). 
Rusnawati. (2012). Faktor-Faktor yang Berhubungan dengan Pemilihan Tempat Persalinan di Wilayah Kerja Puskesmas Negara Kecamatan Daha Utara Kabupaten Hulu Sungai Selatan Provinsi Kalimantan Selatan Tahun 2012. Thesis. Fakultas Kesehatan Masyarakat. Universitas Indonesia. Jakarta.

Sibua., Siska N., and Rombot, D. V. (2015). Faktor-faktor yang berhubungan dengan keputusan pemilihan tempat bersalin di wilayah kerja Puskesmas Perawatan Kecamatan Ibu Kabupaten Halmahera Barat Propinsi Maluku Utara. Thesis: Fakultas Kedokteran Universitas Sam Ratulangi Manado.

Syam, et al. (2015). Perilaku Pengambilan Keputusan Oleh Ibu Hamil dalam Pencarian Pelayanan Kesehatan di Wilayah Kerja Pesisir Kota Palu. Universitas Hasanuddin

Wulandari. (2016) Gambaran Pengambilan Keputusan Saat Proses Rujukan dari Tingkat Primer ke Tingkat Sekunder di Rumah Sakit Umum Daerah Semarang. JKS. Vol. 1, No. 2 